term research investigations are run, and the council is pleased to announce the employment of full-time research assistants at Preston Montford and Orielton.

The programmes of the different centres are full as usual. Courses offered this year range from 'Energy Relations in an Aquatic Ecosystem" at Slapton Ley from July 17-24, to "Some Aspects of Geomorphology" at Orielton from July 31-August 7. There are also arrangements for independent groups to work at the ientres.

\section{Congress and the "Hidden War"}

ONE of the powerful committees of the US Congress has taken up the International Biological Programme (IBP) in a big way. The Sub-committee on Science, Research and Development (led by House Representative Emilio P. Daddario) of the Committee on Science, and Astronautics may seem a strange forum for discus. sion of the IBP to those not learned in the infra-strueture of congressional committees, but, after all, the Earth is a planet like any other and more like than unlike in its capacity for sustaining biologically irreversible damage from the casual activities of man.

This is the theme of what is certain to be called the Daddario report ("The International Biological Program, its Meaning and Needs", published March 20, 1968). American participation in the IBP is seen as the major opportunity for breakout from a position of siege in "conflict between man and nature in a 'hidden war' with possibly disastrous consequences . . . which may be of a magnitude to dwarf any military war yet fought on Earth and of a scope to reduce any conventional type of combat to relative unimportance". The report spells out some of the potential disasters ahead if total environment (ecological) effects are disregarded, and makes recommendations on what can be done about it. In sum, this congressional group does not want to be part of a civilization which may go down in history "as an elegant technological society struck down by biological disintegration for lack of ecological understanding".

The seriousness of the situation and the importance of ecology in providing answers have so far escaped both the administration and general public. Representative Daddario points out that ". . . this is the most restrictive element which faces US participation in the IBP. ... Such concern as has been evidenced thus far by the Government-and that concern is relatively mildseems to have been fostered more by the conditioned response of Government to the prestige of the scientific community than to an understanding of the problem itself. This situation must change- or the IBP is not likely to get off the ground." This could wrell be echoed for the IBP as a whole.

Seven danger areas or practices are cited in the report: thermal pollution from the nuclear power programme, which is expected to supply as much electricity as serviced the whole of the United States 25 years ago and for which all the large freshwater flow sites have already been tagged for possible nuclear plant cooling; the rise in heat production through urbanization and population increase; radical changes in the atmospheric balance through similar causes plus jet travel; upset of the oxygen/carbon dioxide cycle through defoliation practices (likn those employed in Vietnam) and general reduction in global plant cover; the ruining of freshwater reserves by waste pollution-it is estimated that 500 years would be required to restore Lake Erie to the condition of only 25 years ago if all human polluting activity were halted immediately; loss of useful wildlife species"the prospect... of man living alone on his planet except for domesticated food animals and pets seems rather a dreary one"; the uncertainties of "human. quality control" opened up by genetic advances. "New data on a total environmental system of the type proposed by the IBP are apparently the only way out of the present dilemma which pits alarm versus indifference", the report comments.

The sub-committee criticizes both the organization and funding of the IBP in the United States. It recommends an adequate full-time staff and tighter managerial control and urges that the present ad hoc funding methods be dropped. Estimates of the cost of the US IBP programme (see Nature, 216, 842; 1967) have ranged from $\$ 50$ million to $\$ 200$ million. The sub-committee does not consider that the programme is sufficiently advanced to justify the $\$ 11$ million proposed for the first operational year (1969 in this case), but recommends the Federal Government to provide not less than $\$ 3$ million and not more than $\$ 5$ million for this period. Current rethinking may have the effect of consolidating the major US IBP projects into a single programme consistent with the theme of ecosystem analysis, with a consequent fall in "new money" demands to as little as $\$ 30$ million. "To accomplish a great deal with $\$ 30$ million may in the end not aceomplish enough."

\section{Unrest among French Scientists \\ from our Paris Correspondent}

Some 250 French scientists, together with representatives of several political parties, virtuously gave up the first Sunday of spring in order to hold in Paris a National Research Symposia. Even if the problems discussed were not defined particularly clearly and the solutions envisaged were in many cases vague or unrealistic, this event is in itself extremely significant. In effect, it marks an important stage in a development which seems to have been slower to take place in France than elsewhere. This is the consciousness of research workers that they belong to a single community which ought, in the face of public and government opinion, to define its objectives.

The speeches made were somewhat disparate, but there was a measure of agreement. Professors Kourilsky, Hamburger and Mathé, for example, deplored the way in which medical research in faculties of medicine and university teaching hospitals is run by the teachers and clinical workers, who enjoy a higher status than the rest. They traced a comparison (which was flattering for Great Britain) between conditions on either side of the Channel. For the rest, two preoccupations seemed to dominate most of the speechesthe need for a more coherent organization and for a more efficient deployment of research facilities. On both these themes there was a wide range of opinions, from highly technical discussions to political debates.

But the political contributions were generally dominant, and not all were on a happy note. Some of the outbursts from university factions wavered between a 